\title{
Survey of ultraviolet radiation-absorbing mycosporine-like amino acids in organs of coral reef holothuroids*
}

\author{
J. Malcolm Shick ${ }^{1,2}$, Walter C. Dunlap ${ }^{2}$, Bruce E. Chalker ${ }^{2}$, Anastazia T. Banaszak ${ }^{3}$, \\ Teresa K. Rosenzweig ${ }^{4, * *}$
}

'Departments of Zoology and Oceanography, and Center for Marine Studies, University of Maine, 5751 Murray Hall, Orono, Maine 04469-5751, USA

${ }^{2}$ Australian Institute of Marine Science, PMB No. 3, Townsville M. C., Queensland 4810, Australia

${ }^{3}$ Department of Biological Sciences, University of California, Santa Barbara, California 93106, USA

${ }^{4}$ The Flinders University of South Australia, Bedford Park, South Australia 5061, Australia

\begin{abstract}
Twelve deposit-feeding species of tropical holothuroid echinoderms (families Holothuriidae and Stichopodidae) were surveyed for the presence of UV-absorbing mycosporine-like amino acids (MAAs) during Austral summer at Hicks Reef, Great Barrier Reef (GBR). An additional species belonging to the Synaptidae was collected in Austral winter from Shrimp Reef, GBR. Tissues of all species contained MAAs, including mycosporine-glycine, shinorine, porphyra-334, mycosporine-2 glycine, palythine, asterina-330 and palythinol. The MAAs in holothuroids occur predominantly in their epidermis, which suggests a photoprotective function, since the highest concentrations of these UVabsorbing compounds would be expected in tissues directly exposed to sunlight. Concentrations of

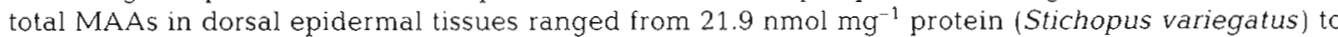

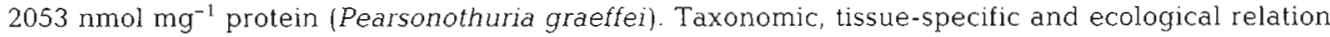
ships in the occurrence of MAAs in tropical deposit-feeding holothuroids are discussed
\end{abstract}

\section{INTRODUCTION}

Owing to the high transparency of tropical ocean waters, shallow-dwelling organisms there are exposed to high fluxes of UV-A (320 to $400 \mathrm{~nm}$ ) and UV-B (280 to $320 \mathrm{~nm}$ ) radiation (Jerlov 1950, Smith \& Baker 1979 , Fleischmann 1989). Biochemical defenses against this include blocking potentially harmful wavelengths with UV-absorbing compounds, 1 group of which has absorption maxima centered around $320 \mathrm{~nm}$. These 'S-320 compounds' were first detected in several reefbuilding corals and a blue-green alga by Shibata (1969). Since identified as a family of compounds known as mycosporine-like amino acids (MAAs), they have been found in a wide variety of marine organ-

- Contribution number 627 from the Australian Institute of Marine Science

- Present address: Coherent Scientific, 138 Greenhill Road Untley, South Australia 5061, Australia isms, including dinoflagellates (Carreto et al. 1990), macroalgae (Sivalingam et al. 1974, Wood 1987), diverse corals, zoanthids, sea anemones and other anthozoans (Takano et al. 1978, Hirata et al. 1979, Dunlap \& Chalker 1986, Shick et al. 1991), and an assortment of Antarctic marine organisms (Karentz et al. 1991).

Because MAAs consistently were found either in algae or in algal-invertebrate symbioses, and given that the pathway of their biosynthesis seems to be restricted to algae, bacteria and fungi (Yoshida 1969, Floss 1979, Favre-Bonvin et al. 1987), it has been inferred that the compounds present in symbiotic coelenterates are localized in their zooxanthellae, or translocated from these algae to the host (e.g. Dunlap \& Chalker 1986). However, MAAs also occur in nonsymbiotic animals, including bivalve molluscs (Chioccara et al. 1986a), echinoderms (Nakamura et al. 1981, Chioccara et al. 1986b) and fishes (Dunlap et al. 1989). Alternative origins of the compounds in the animals, either dietary or de novo synthesis, therefore exist. 
Holothuroid echinoderms of the order Aspidochirotida are the most important deposit-feeders on coral reef sediments (Bakus 1973, Moriarty et al. 1985, Féral $\&$ Cherbonnier 1986). Their diet, culled from among the larger mass of sediment particles, includes bacteria, filamentous cyanobacteria, red algae and foraminiferans (Bakus 1968, Moriarty 1982). Although many of these holothuroids are cryptic or nocturnally active, many others are active foragers in shallow water in daylight (Bakus 1968, Hammond 1982, Cannon \& Silver 1986, Féral \& Cherbonnier 1986). Therefore they may require protection from UV radiation, and were included in ongoing surveys of coral reef organisms for the presence of mycosporine-like amino acids. The morphological complexity of holothuroids presents the opportunity to examine organ-specific differences in MAA content that may be related to differences in UV exposure.

\section{MATERIALS AND METHODS}

Holothuroids were collected in December 1988 during daylight by scuba diving or snorkeling at depths of 1 to $20 \mathrm{~m}$ (usually $10 \mathrm{~m}$ or shallower) at Hicks

Table 1. Species of holothuroids (Order Aspidochirotida) on Hicks Reef examined for the presence of mycosporine-like amino acids, with notes on the habits and habitats of the species. A representative of Order Apodida from Shrimp Reef is also included. Depth ranges are those reported for the species in New Caledonia by Féral \& Cherbonnier (1986); depths in parentheses are those at which specimens in the present study were collected. Notes are compiled from Cannon \& Silver (1986), Féral \& Cherbonnier (1986) and our observations

\begin{tabular}{|c|c|c|}
\hline Order/Family/Species & Depth rangc & Notes \\
\hline \multicolumn{3}{|l|}{ Aspidochirotida } \\
\hline \multicolumn{3}{|l|}{ Holothuriidae } \\
\hline Actinopyga echinites (Jaeger) & $0-30 \mathrm{~m}$ & $\begin{array}{l}\text { On many substrates hard and sandy, on coral rub- } \\
\text { ble and among living corals; withstands intertidal } \\
\text { exposure; dorsal epidermis often covered with fine } \\
\text { sand }\end{array}$ \\
\hline Actinopyga lecanora (Jaeger) & $0-20 \mathrm{~m}$ & $\begin{array}{l}\text { Mostly on hard substrates, often concealed among } \\
\text { coral rubble; active only at night }\end{array}$ \\
\hline Bohadschia argus Jaeger & $\begin{array}{l}2-40 \mathrm{~m} \\
\text { usually } 6-8 \mathrm{~m}(4 \mathrm{~m})\end{array}$ & $\begin{array}{l}\text { Fully exposed on coral sand and rubble; readily } \\
\text { ejects Cuvierian tubules }\end{array}$ \\
\hline Holothuria (Halodeima) atra Jaeger & $\begin{array}{l}0-3 \mathrm{~m} \\
(1 \mathrm{~m})\end{array}$ & $\begin{array}{l}\text { Ubiquitous except on outer reef slope, fully exposed } \\
\text { in shallow water, often on sand flats; epidermis } \\
\text { usually with a coating of sand }\end{array}$ \\
\hline Holothuria (Halodeima) edulis Lesson & $0-45 \mathrm{~m}$ & $\begin{array}{l}\text { In many reef habitats, exposed on various sub- } \\
\text { strates or among coral rubble; never with sand } \\
\text { coating }\end{array}$ \\
\hline Holothuria (Microthele) fuscopunctata Jaeger & $\begin{array}{l}5-20 \mathrm{~m} \\
(12 \mathrm{~m})\end{array}$ & In reef lagoon, on sand near seagrasses \\
\hline Holothuria (Microthele) nobilis (Selenka) & $0-40 \mathrm{~m}$ & Exposed on rubble or seagrasses \\
\hline Pearsonothuria graeffei ${ }^{a}$ (Semper) & $5-30 \mathrm{~m}(1 \mathrm{~m})$ & $\begin{array}{l}\text { Exposed on hard substrates encrusted with coral- } \\
\text { line algae; active diurnally and nocturnally }\end{array}$ \\
\hline \multicolumn{3}{|l|}{ Stichopodidae } \\
\hline Stichopus chloronotus Brandt & $\begin{array}{l}0-2 \mathrm{~m} \text {, large } \\
\text { specimens to } 15 \mathrm{~m}(1 \mathrm{~m})\end{array}$ & On outer reef flat, often among coral debris \\
\hline Stichopus variegatus Semper & $\begin{array}{l}0-30 \mathrm{~m} \\
(<5 \mathrm{~m})\end{array}$ & On fine sediments of sand flats and lagoons \\
\hline Thelenota ananas Jaeger & $\begin{array}{c}2-30 \mathrm{~m} \\
\text { (various) }\end{array}$ & $\begin{array}{l}\text { Exposed on large coral debris, on coral sand in reef } \\
\text { gutters }\end{array}$ \\
\hline Thelenota anax H. L. Clark & $12-30 \mathrm{~m}$ & $\begin{array}{l}\text { Deep water on soft sediments; sometimes found } \\
\text { with Holothurla fuscopunctata }\end{array}$ \\
\hline \multicolumn{3}{|l|}{ Apodida } \\
\hline \multicolumn{3}{|l|}{ Synaptidae } \\
\hline Synapta maculata (Chamisso and Eysenhardt) & $\begin{array}{c}2-25 \mathrm{~m} \\
(6 \mathrm{~m})\end{array}$ & $\begin{array}{l}\text { Exposed on coral sand and rubble, sometimes } \\
\text { among sea grass }\end{array}$ \\
\hline
\end{tabular}


Reef, Great Barrier Reef (GBR), Australia (145 $29^{\prime} \mathrm{E}$, $\left.14^{\circ} 27^{\prime} \mathrm{S}\right)$. Because many of the specimens were collected opportunistically by volunteer divers while on other missions, the actual collection depths are not known for some individuals. All specimens were collected from fully exposed, unshaded habitats. An additional specimen of Holothuria nobilis and a specimen of Synapta maculata were collected in July 1991 at Shrimp Reef, GBR $\left(148^{\circ} 05^{\prime} \mathrm{E}, 1^{\circ} 57^{\prime} \mathrm{S}\right)$. Table 1 presents a list of species collected, their depth ranges reported in Féral \& Cherbonnier (1986), actual collection depths where known, and natural history notes summarized from Féral \& Cherbonnier (1986). Cannon \& Silver (1986) and our observations. The nomenclature is from Féral \& Cherbonnier (1986).

Shortly after specimens were returned to the RV 'Lady Basten', small pieces of various organs were excised, minced and blotted free of adhering fluid. In particular, epidermal tissue was removed using a razor blade or scalpel, taking care to cut only as deep as the extent of the pigmented layer. The underlying body wall was sampled from the side of the perivisceral coelomic cavity, and included the inner epithelium as well as a larger mass of dermis; circular muscles were avoided when excising the body wall sample. Intestinal wall tissue was taken from the mid-region of that organ. Samples of respiratory trees and gonads were free of hemal tissue. Entire tentacles were sampled. Pieces of longitudinal muscle were separated from the body wall, and care was taken to remove cloacal tissues separately from the intestine.

Minced tissues were sequentially extracted 3 times for $20 \mathrm{~min}$ in $3 \mathrm{~cm}^{3}$ of $100 \%$ methanol. The combined extract was clarified by centrifugation and analyzed aboard ship for mycosporine-like amino acids. Individual MAAs were separated by reverse-phase isocratic HPLC on a Brownlee RP-8 column (Spheri-5, $4.6 \mathrm{~mm}$ ID $\times 25 \mathrm{~cm}$ ) protected with an RP-8 guard column (Spheri-5, $4.6 \mathrm{~mm} \mathrm{ID} \times 5 \mathrm{~cm}$ ), with an aqueous mobile phase containing $0.1 \%$ acetic acid and $25 \%$ methanol ( $\mathrm{v}: \mathrm{v})$ at a flow rate of $0.8 \mathrm{~cm}^{3} \mathrm{~min}^{-1}$. A higher concentration of methanol ( 55 or $75 \%$ ) was required to resolve the extremely polar MAAs shinorine, porphyra-334 and mycosporine-2 glycine (W. R. Stochaj, W. C. Dunlap \& J. M. Shick unpubl.). Detection of peaks was by UV absorbance at 313 and $340 \mathrm{~nm}$. Identities of peaks were confirmed by the wavelength method (ratio of peak areas detected at $313 \mathrm{~nm} / 340$ $\mathrm{nm}$ ) and by co-chromatography with standards of mycosporine-glycine, palythine and palythinol from the zoanthid Palythoa tuberculosa (Hirata et al. 1979), porphyra-334 and shinorine from the red alga Porphyra tenera ('nori') (Takano et al. 1979, Tsujino et al. 1980), asterina-330 from the ocular lens of Plectropomus leopardus (Dunlap et al. 1989), and mycosporine-2 gly- cine from the sea anemone Anthopleura elegantissima (W. R. Stochaj, W. C. Dunlap \& J. M. Shick unpubl.). Peaks were integrated on Hewlett-Packard or SpectraPhysics integrators, and quantification of individual MAAs was corrected for extraction efficiency as described in Dunlap \& Chalker (1986) and Dunlap et al. (1989), using published molar extinction coefficients summarized by those authors and from Takano et al. (1979) and Tsujino et al. (1980). The molar extinction coefficient for mycosporine-2 glycine was assumed to be the same as that of the structurally similar compound shinorine. Extraction coefficients $\left(E_{3} ; 3 \times 3 \mathrm{~cm}^{3}\right.$ methanol) are: mycosporineglycine (0.980); shinorine (0.974); porphyra-334 (0.933); mycosporine-2 glycine (0.942); palythine (0.966); asterina-330 (0.968); and palythinol (0.968).

Methanol-extracted tissues were frozen and returned to the Australian Institute of Marine Science for determination of their protein content. Rehydrated tissues were digested in hot $1 \mathrm{~N} \mathrm{NaOH}$, and after being cooled, neutralized and diluted, the mean protein content of triplicate aliquots was measured by the method of Bradford (1976) using Coomassie Brilliant Blue with bovine gamma globulin standards (Bio-Rad Laboratories).

\section{RESULTS AND DISCUSSION}

HPLC separations of the methanolic extracts of epidermal and gut tissues from Thelenota ananas are shown in Fig. 1. The chromatograms indicate the presence of 7 mycosporine-like amino acids, the structures of which are given in Fig. 2. The taxonomic and tissue distributions of these MAAs in the species surveyed are shown in Figs. 3 to 7 . Although most species are represented by a single specimen each, a measure of intraspecific varation is available for $T$. ananas (Fig. 6) and indicates that organ- and species-specific differences in MAAs can be discerned with some confidence. These results are discussed in several contexts: taxonomic and tissue distribution of MAAs, ecology of the species, and qualitative biochemistry.

The concentration of MAAs in the epidermis is generally higher in members of the family Holothuridae than in the Stichopodidae (cf. Figs. 3 to 5 with Fig. 6), and intermediate in the single specimen representing the apodid Synaptidae (Fig. 7). Within the Holothuriidae, the predominant epidermal MAAs tend to be least concentrated in Holothuria (Halodeima) spp. (ca 60 to

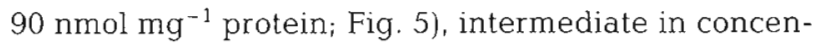

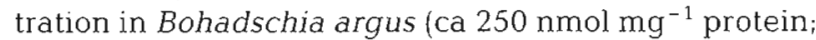
Fig. 4), intermediate to high in Actinopyga spp. (ca 250 to $650 \mathrm{nmol} \mathrm{mg}^{-1}$ protein; Fig. 3), and extremely concentrated in Pearsonothuria (formerly Bohadschia) 

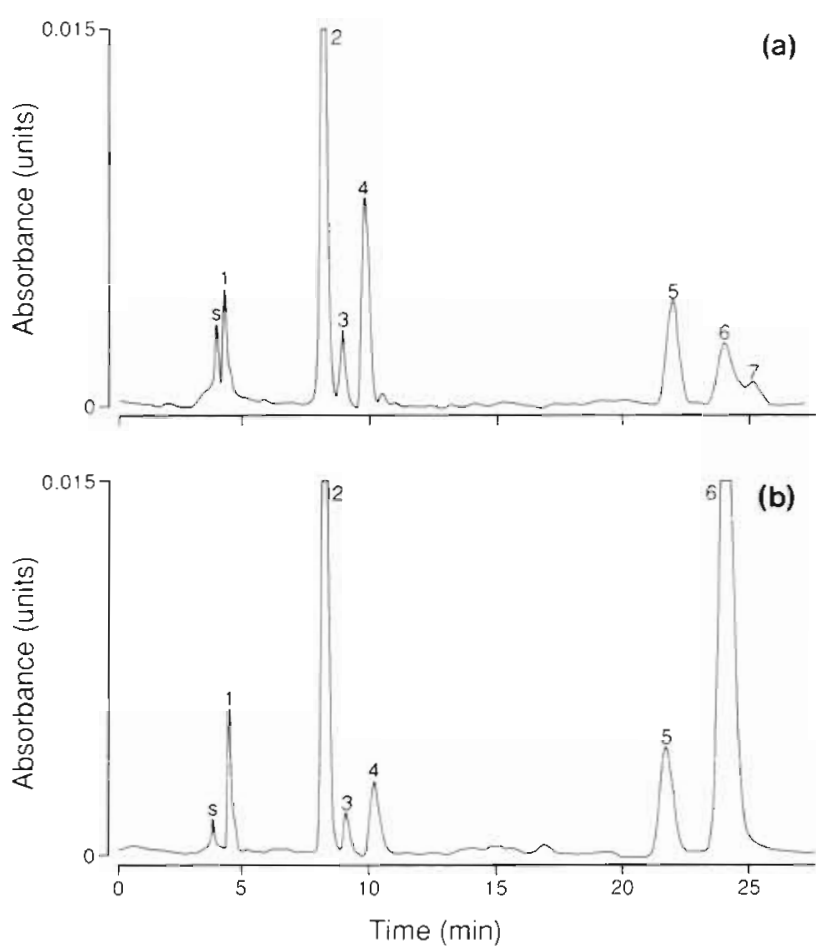

Fig. 1 Thelenota ananas. High performance liquid chromatographic separation of the mycosporine-like amino acids in methanolic extracts of (a) the gut wall and (b) the epidermis of $T$. ananas. Peak identification numbers: $1=$ mycosporine-glycine $; 2=$ shinorine $3=$ porphyra $-334 ; 4=$ mycosporine -2 gly cine $;=$ palythine; $6=$ asterina $-330 ; 7=$ palythinol $\mathrm{S}=$ salts (refractive)

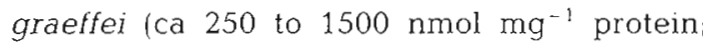
Fig. 4). The $1461 \mathrm{nmol}$ of asterina-330 per $\mathrm{mg}$ protein in $P$ graeffei is equivalent to $0.421 \mathrm{mg}$ of asterina-330 per $\mathrm{mg}$ tissue protein. The 2 species of Holothuria (Microthele) show distinct qualitative and quantitative differences in their MAAs (Fig. 5). Unlike all other holothuroids examined, $H$. (Microthele) fuscopunctata virtually lacked asterina-330 in its epidermis and other tissues; the predominance of mycosporine-glycine and shinorine in this species suggests that it lacks a metabolic pathway to produce asterina-330. Both the absence of asterina-330 and the relatively low concentrations of other MAAs may be related to the restriction of this species to depths below $5 \mathrm{~m}$ (Féral \& Cherbonnier 1986) and hence its exposure to lower levels of UV radiation (see below).

Within the Stichopodidae, the total content of MAAs in the epidermis is relatively evenly distributed among 4 to 6 of the 7 MAAs, with mycosporine-glycine, shinorine, palythine and asterina-330 predominating (Fig. 6). The same applies to the apodid Synapta maculata (Fig. 7).
The epidermal concentrations of the most abundant MAAs in Stichopus spp. (ca 30 to $40 \mathrm{nmol} \mathrm{mg}^{-1}$ protein) tend to be lower than in Thelenota ananas (ca 40 to $70 \mathrm{nmol} \mathrm{mg}{ }^{-1}$ protein) collected at similar depths. The lower epidermal MAA concentration in $T$. anax than in $T$. ananas may reflect the greater depth at which the former species lives (see Cannon \& Silver 1986, Féral \& Cherbonnier 1986).

The MAAs in holothuroids occur predominantly in their epidermis. This may have an adaptive basis, since the highest concentration of these UV-protective compounds would be expected in tissues directly exposed to sunlight. Concentrations of the major individual

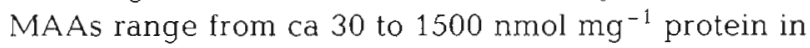
the species surveyed. For comparision, MAA concentrations in scleractinian corals, actiniarians and alcyonaceans exposed to similar irradiances in shallow water average 50 to $300 \mathrm{nmol} \mathrm{mg}^{-1}$ protein (Dunlap \& Chalker 1986, Shick et al. 1991j and decline to 10 io $20 \mathrm{nmol} \mathrm{mg}{ }^{-1}$ protein in corals at $20 \mathrm{~m}$ depth (Dunlap et al. 1986).

The highest concentration of MAAs occurs in the epidermis of Pearsonothuria graeffei, a species that is noted for being active in daylight (Cannon \& Silver 1986, Féral \& Cherbonnier 1986). Although the latter authors report $P$. graeffei to occur only below $5 \mathrm{~m}$ in New Caledonia, our specimen was collected at a depth of $1 \mathrm{~m}$ on the reef flat, where UV fluxes are very high (Fleischmann 1989). Intrageneric comparisons also
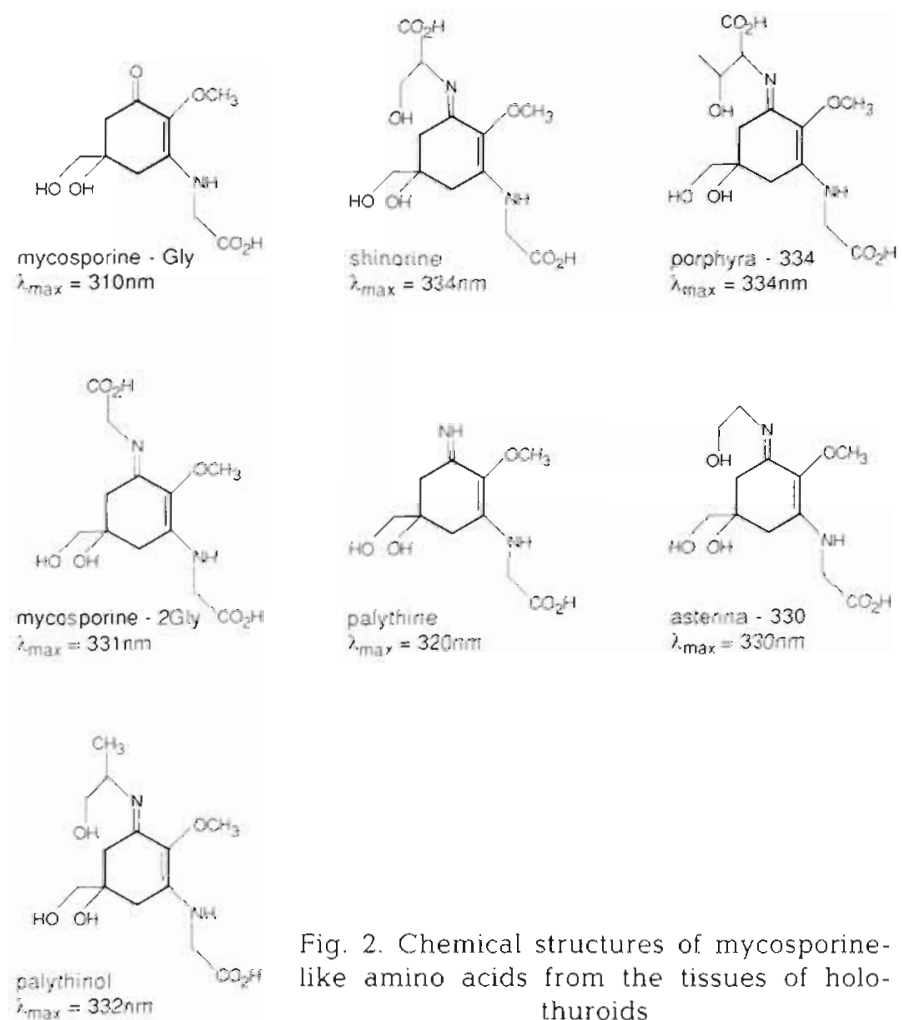

Fig. 2. Chemical structures of mycosporinelike amino acids from the tissues of holothuroids 
suggest a correlation between depth-related UV exposure and epidermal MAA concentration: Thelenota ananas occurs as shallow as $2 \mathrm{~m}$ and has higher concentrations of MAAs than does T. anax (Fig. 6), which occurs only below $5 \mathrm{~m}$. Similarly, Holothuria (Microthele) nobilis ranges as shallow as $1 \mathrm{~m}$ or less, and its epidermal MAAs are an order of magnitude more concentrated than those in $H$. (Microthele) fuscopunctata (Fig. 5), which lives at $5 \mathrm{~m}$ and deeper. The data of Fleischmann (1989) indicate that UV radiation (300 to $400 \mathrm{~nm}$ ) measured at a depth of $5 \mathrm{~m}$ in tropical seawater is ca 60 to $80 \%$ of that incident at the surface. The depth range over which an individual holothuroid may move is unknown, and Conand (1991) has shown that vagility varies greatly among several species examined, so the concentrations of MAAs in a given individual may indicate its UV defenses integrated over time and depth.

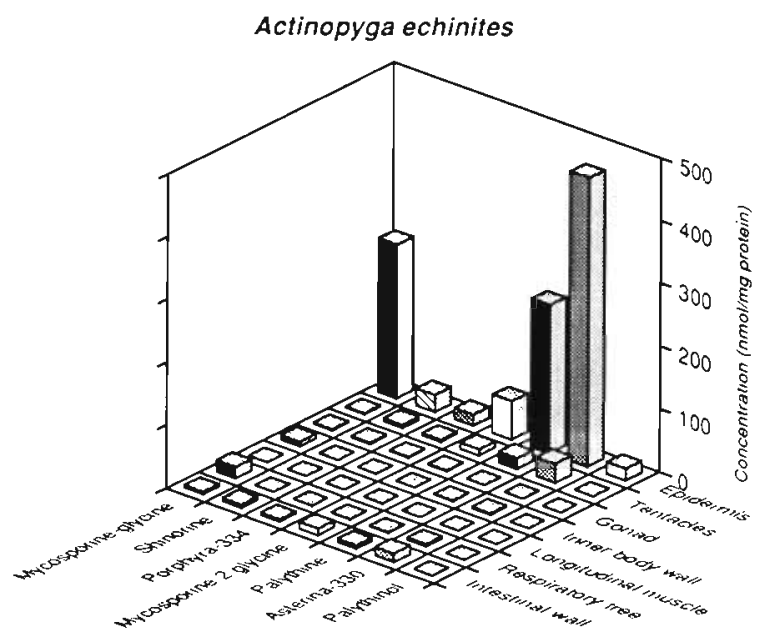

The association between degree of UV exposure and epidermal MAA concentration is not absolute, however. Although Actinopyga lecanora is cryptic and exclusively nocturnal, it had epidermal MAA concentrations as high or higher than the diurnally-active A. echinites living at the same depth (Fig. 3). In this case, such a high MAA concentration may be characteristic of the genus. Conversely, Stichopus chloronotus lives exposed in extremely shallow water and $S$. variegatus is common on shallow sand flats and lagoons, yet their epidermal MAA concentrations were $40 \mathrm{nmol}$ $\mathrm{mg}^{-1}$ protein or less, the lowest we have measured in holothuroid epidermal tissues, which again may be typical of this genus. In $S$. chloronotus, some UV protection may be afforded by its especially dense, greenish epidermal pigmentation, which is darker under conditions of higher irradiance (Féral \& Cherbonnier 1986).

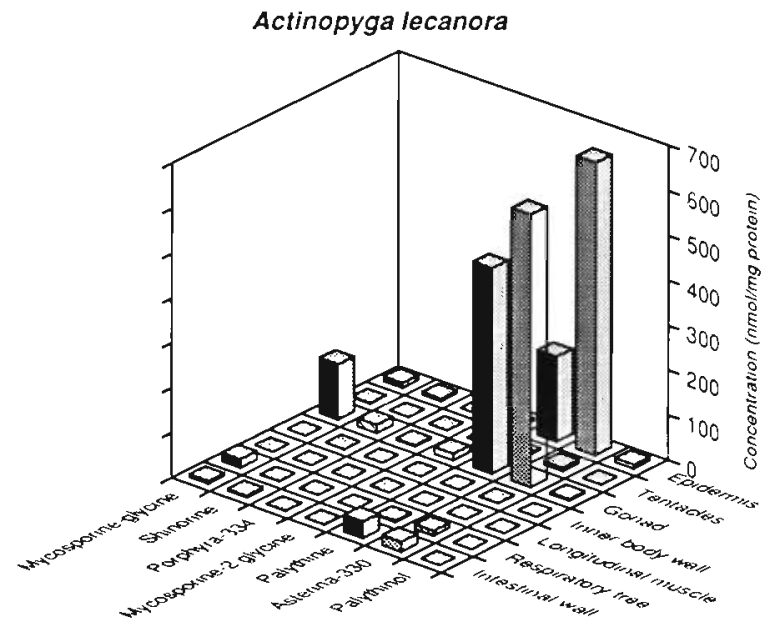

Fig. 3. Actinopyga echinites, Actinopyga lecanora. Concentration and organ distribution of mycosporine-like amino acids in 2 members of the family Holothuriidae
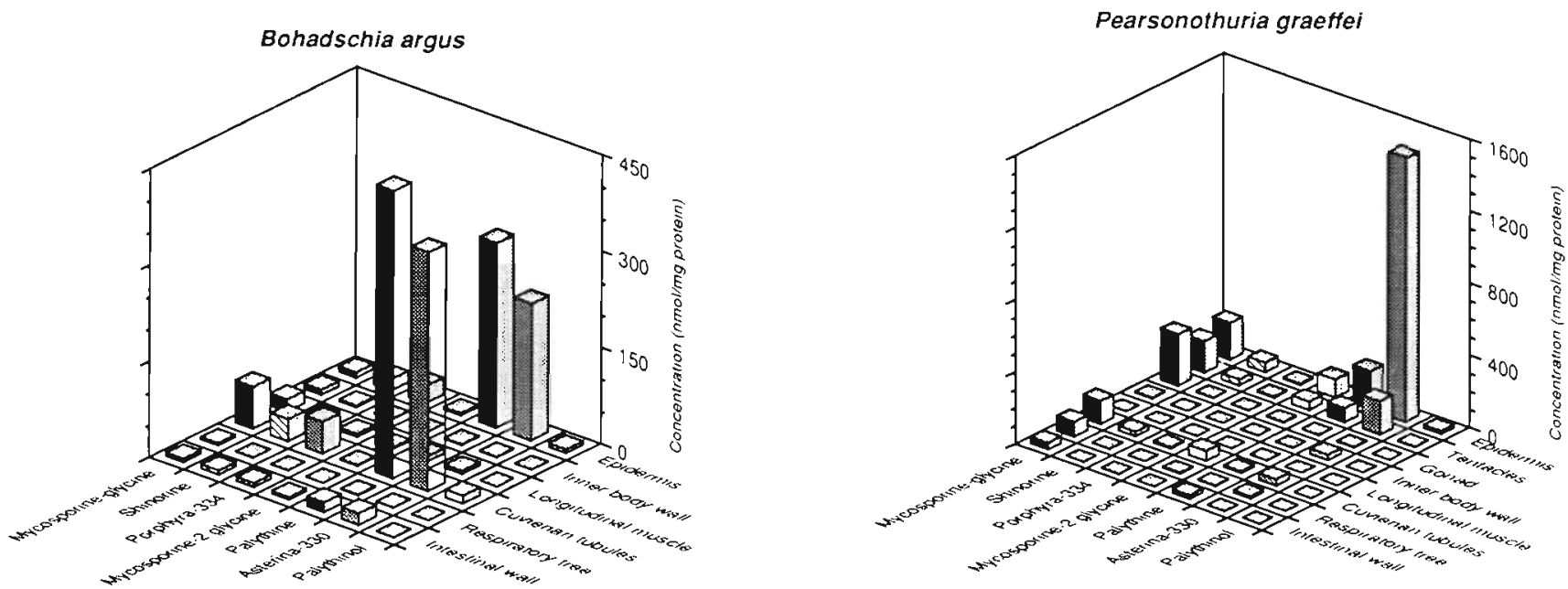

Fig. 4. As in Fig. 3 but for Bohadschia argus and Pearsonothuria graeffei 

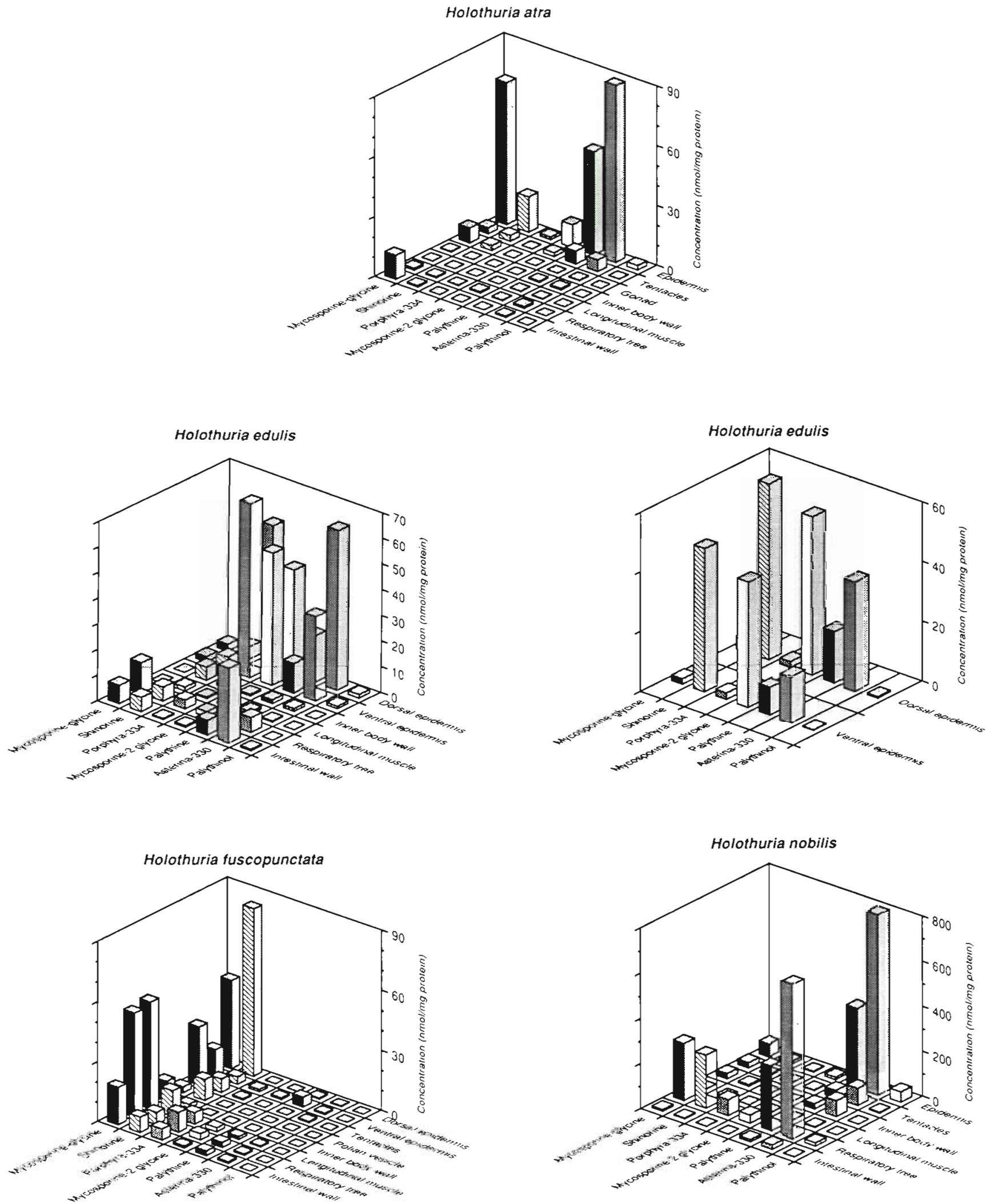

Fig. 5. As in Fig. 3 but for Holothuria (Halodema) atra, H. (Halodelma) edulis (2 specimens), H. (Microthele) fuscopunctata and $H$. (Microthele) nobilis 

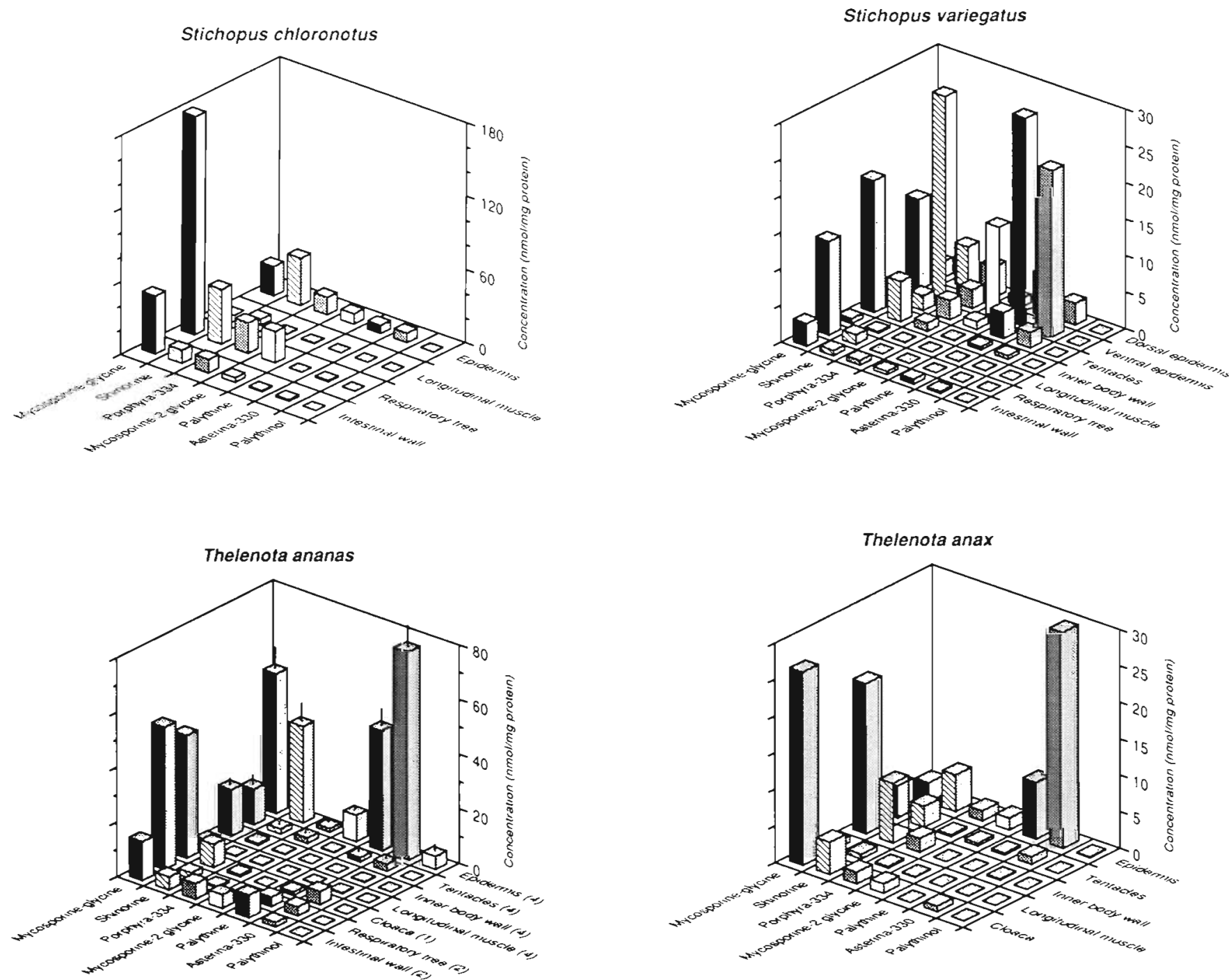

Fig. 6. Stichopus chloronotus, S. variegatus, Thelenota ananas, T. anax. Concentration and organ distribution of mycosporine-like amino acids in 4 members of the family Stichopodidae. For $T$. ananas, numbers in parentheses indicate no. of specimens tested, and vertical lines atop bars indicate $+1 \mathrm{SE}$ where $n=4$

The tentacles of these deposit-feeding holothuroids are also exposed to direct and reflected sunlight, and these tissues are relatively rich in MAAs in some species. Their ventral position presumably shades the tentacles somewhat, which may account for their lower concentration of MAAs than in the dorsal epidermis. Pearsonothuria graeffei and Synapta maculata, however, extend their tentacles anteriorly when foraging (see photographs in Féral \& Cherbonnier 1986) and the concentrations of the predominant MAAs in these species were the highest we have seen in holothuroid ten tacles. Similarly, the 4 predominant MAAs were all more concentrated in dorsal than in ventral epidermis of 1 specimen of Holothuria (Halodeima) edulis, although only 2 of the 4 were more concentrated in the dorsal epidermis of a second specimen (Fig. 5). In Stichopus variegatus, all MAAs are more concentrated in the ventral than in the dorsal epidermis, but the MAA concentrations (maximum $<30 \mathrm{nmol} \mathrm{mg}^{-1}$ protein) in this species of sea cucumber were the lowest of any that we measured.

With few exceptions, epidermal tissues contain the highest concentrations of MAAs, which is consistent with a postulated adaptive function of the compounds in UV photoprotection. This conclusion must be tempered by the finding that the MAA concentration in fish ocular lenses bears no apparent relationship to feeding depth or extent of diurnal activity (Dunlap et al. 1989). The pattern presented by the remaining organs in holothuroids is a mixed one, and it is clear that UV exposure is not the sole determinant of MAA concentration. Other factors, including the embryological origin of the various tissues, apparently are involved.

Gonads contained detectable to large amounts of 


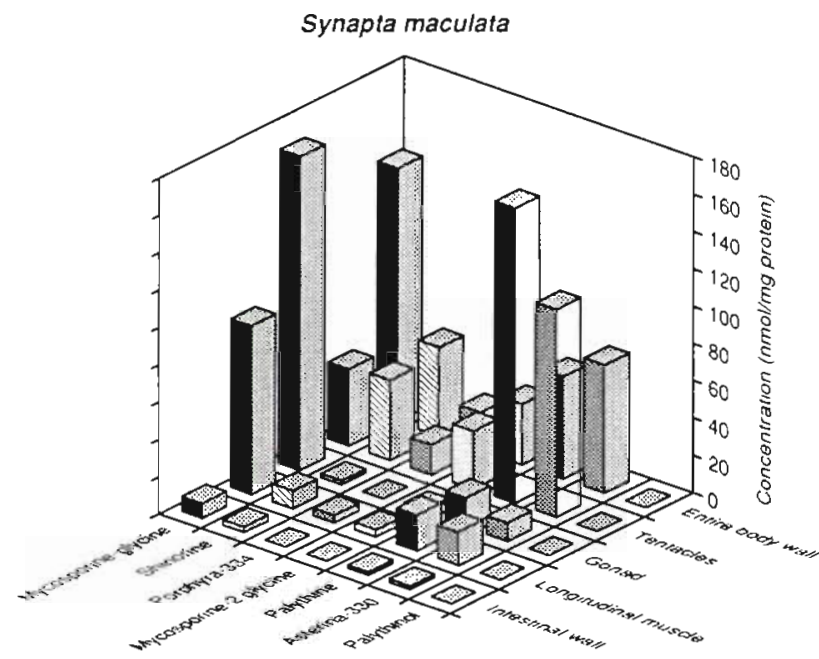

Fig. 7 Synapta maculata. Concentration and organ distribution of mycosporine-like amino acids in 1 member of the family Synaptidae

MAAs in 3 of the 4 species examined at Hicks Reef (Figs. 3 to 5); MAAs were essentially absent from the gonad of a single reproductively spent specimen of Actinopyga echinites (Fig. 3). Both the ripe testis and spawned sperm of a single specimen of Holothuria nobilis collected at Shrimp Reef in July 1991 contained

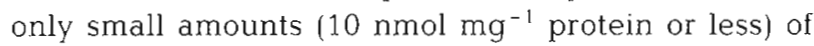
mycosporine-glycine as the only quantifiable MAA. Conversely, mycosporine-glycine was the principal MAA in the gonad (gender undetermined) of Pearsonothuria graeffei, where it reached concentrations of $>300 \mathrm{nmol} \mathrm{mg} \mathrm{mg}^{-1}$ protein (Fig. 4), and in the gonad (gender undetermined) of Synapta maculata, at a con-

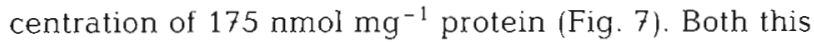
MAA and shinorine were present in the gonad of $H$. atra, but they were absent from other internal organs of this species (Fig. 5). Mycosporine-glycine and shinorine were present in the ripe gonad (gender undetermined) of A. lecanora, and palythine and asterina-330 also achieved very high concentrations in this organ (Fig. 3). Because spawned gametes would require protection from solar UV, the generally high concentration of MAAs in ripe gonads may be adaptive, although the low concentrations in $H$. nobilis testis and sperm confuse this issue. The low concentration of MAAs in $H$. nobilis sperm may reflect a sexual difference, if the individuals of species having high MAA concentrations in the gonads were females; since spawned sperm would be exposed to solar UV for far less time than eggs or developing embryos and larvae, the sperm may not require such high concentrations of MAAs as the eggs. The absorption spectra of the 4 MAAs in the gonad span 310 to $334 \mathrm{~nm}$, much of the range of biologically damaging solar UV.
The presence of high concentrations of MAAs in the gonad was in sharp contrast to the virtual absence of these compounds from longitudinal muscle; only in 2 of the 13 species examined (Holothuria fuscopunctata and Synapta maculata) were there appreciable amounts (ca 60 and $90 \mathrm{nmol} \mathrm{mg}^{-1}$ protein, respectively) of mycosporine-glycine in the longitudinal muscle (Figs. $5 \& 7$ ). In the case of $S$. maculata, its very thin, translucent body wall may afford less UV protection to the underlying longitudinal muscle and require endogenous defenses in that tissue. MAAs likewise were nearly absent from the inner body wall (consisting of inner epithelium and dermis, both of mesodermal origin) in 7 of the 12 species studied at Hicks Reef. The MAAs present in 4 species (H. fuscopunctata, Stichopus variegatus, Thelenota ananas and T. anax) were mycosporine-glycine and shinorine; concentrations were generally $<20 \mathrm{nmol} \mathrm{mg}^{-1}$ protein. These compounds were also present at similar levels in body wall of $H$. nobilis, which exceptionally contained $70 \mathrm{nmol}$ asterina-330 $\mathrm{mg}^{-1}$ protein (Fig. 5). Apart from these few examples, the data suggest that internal, mesodermal tissues removed from UV exposure do not appreciably accumulate MAAs. The occurrence of mycosporine-glycine and shinorine in the inner body wall may indicate their transport from the gut to the epidermis via this route (see below).

Surprisingly high concentrations of mycosporineglycine and shinorine were present in the cloaca and respiratory trees of many species in both the Holothuriidae and Stichopodidae, and in the Cuvierian tubules of Bohadschia argus and Pearsonothuria graef$f e i$. The Cuvierian tubules of $B$. argus also contained very large amounts of palythine and asterina-330, a pattern similar to the epidermis in this species (Fig. 4). A possible explanation of the seeming exception to the association between UV exposure and MAA concentration is that the cloaca is derived from ectoderm (Runnström 1927, Féral \& Massin 1982); based on their continuity with the cloaca (as distinct from the intestine, the digestive portion of which is endodermal in origin), and on the presence of T-shaped cells characteristic of integumental epithelia (J.-P. Féral pers. comm.), the respiratory trees and Cuvierian tubules also may be ectodermally-derived. Thus, the capacity to accumulate high concentrations of certain MAAs may be characteristic of ectodermal tissues in general, including cloaca, respiratory trees and Cuvierian tubules as well as integumental epidermis.

Intestinal tissue also contained measurable amounts of MAAs in most of the holothuroid species examined. Mycosporine-glycine and shinorine were most frequently encountered, although palythine and asterina330 were also concentrated in some species. Since holothuroids, like other metazoans, probably cannot 
synthesize the mycosporine base structure de novo (see 'Introduction'), the acquisition of MAAs in the diet might account for the presence of these compounds in the gut tissue. Most of the MAAs identified in holothuroid tissues are present in the coral sand (primarily in unicellular algae and cyanobacteria) that they ingest, and appear to be removed from the gut contents as they move through the digestive tract ( $W$. C. Dunlap, J. M. Shick \& R. Larsen unpubl.).

Mycosporine-glycine is structurally the simplest MAA (Fig. 2) and may be the parent compound from which other MAAs are derived in secondary metabolism. It is the most widespread MAA among the holothuroids both taxonomically and in tissue distribution, and it may be that most tissues in most species have some capacity to accumulate it following its transport from the gut. Holothuria fuscopunctata accumulates mycosporine-glycine and shinorine in a similar ratio in most of its tissues (Fig. 5). This species is unusual in the virtual absence of other MAAs from its tissues, whereas Thelenota anax, which may occur in the same habitat, accumulates mycosporine-glycine and shinorine in a ratio similar to $H$. fuscopunctata, but also contains asterina-330 in its epidermis (Fig 6).

Very high concentrations of asterina-330, particularly in epidermis, may be a specific photoadaptation and reflect its selective accumulation in a tissue that receives the highest amount of UV radiation. This is especially indicated because of the virtual absence of asterina-330 from the body wall tissue directly underlying the epidermis, whereas in the latter tissue the concentration may reach several hundred nmol of asterina-330 per mg protein or higher. The epidermal concentration of palythine tends to be high when that of asterina-330 is greatest, and this also may indicate a selective (UV-induced?) synthesis or accumulation of an MAA having an absorption maximum at a shorter wavelength $(320 \mathrm{~nm})$ than asterina-330, thus extending the range of UV-protection. Palythinol is a minor component of the total MAA complement in holothuroids. Its structural similarity to asterina-330, differing only in the methylation of the ethanolimine residue (Fig. 2), and the positive correlation between the epidermal concentrations of these MAAs $\left(\mathrm{r}^{2}=0.45, \mathrm{n}=19\right.$, $p=0.0016)$ in the species examined, suggest that the 2 compounds are metabolically related.

In conclusion, taxonomic, tissue-specific and ecological trends can be discerned in the occurrence of mycosporine-like amino acids in tropical deposit-feeding holothuroids. Unlike coral reef anthozoan cnidarians, where MAAs may be synthesized by their symbiotic dinoflagellates (Dunlap \& Chalker 1986, Shick et al. 1991, see also Carreto et al. 1990), holothuroids do not harbor algal endosymbionts and their MAAs must have a different provenance. Uptake of dietary
MAAs is one possibility that is treated elsewhere (Dunlap et al. 1991, unpubl.). Also of interest are the metabolic interrelationships among algal-derived MAAs and their interconversion by microbes within the holothuroid gut. Whether subcuticular bacteria (see Holland \& Nealson 1978, Féral 1980, Féral \& Massin 1982) have any role in providing MAAs to the animal tissue in these and other echinoderms is unknown, but preliminary electron microscopic examinations of Thelenota ananas do reveal the presence of subcuticular bacteria in this species (K. C. Edwards, J. M. Shick \& W. C. Dunlap unpubl. obs.). In the broad context, the mechanisms for the incorporation of MAAs in holothuroid tissues may provide important insight to a general biochemical pathway for the trophic accumulation of UV-absorbing MAAs in higher marine invertebrates and vertebrates.

Acknowledgements. We thank the masters and crew of RV 'Lady Basten' for logistical support, J. Wu Won for technical assistance, and R. Willis for critical comments on the manuscript. C. Conand, J.-P. Féral and M. Jangoux provided assistance with the literature and valuable insights from their own experience with echinoderms, and 3 anonymous reviewers supplied helpful comments. This research was conducted as part of the Reef Photobiology Program at AIMS. J.M.S. was supported by National Science Foundation Grant DCB8509487 (Physiological Processes), and National Geographic Society research grants $3883-88$ and $4572-91$; his participation in the research was facilitated by a sabbatical leave from the University of Maine and by the visiting investigator program at AIMS.

\section{LITERATURE CITED}

Bakus, G. J. (1968). Defensive mechanisms and ecology of some tropical holothurians. Mar. Biol. 2: 23-32

Bakus, G. J. (1973). The biology and ecology of tropical holothurians. In: Jones, O. A., Endean, R. (eds.) Biology and geology of coral reefs, Vol. 2, Biology 1. Academic Press, New York, p. 325-367

Bradford, M. M. (1976). A rapid and sensitive method for the quantitation of microgram quantities of protein using the principle of protein-dye binding. Anal. Biochem. 72 : $248-254$

Cannon, L. R. G., Silver, H. (1986). Sea cucumbers of Northern Australia. Queensland Museum, Brisbane

Carreto, J. I., Carignan, M. O., Daleo, D., Demarco, S. G (1990). Occurrence of mycosporine-like amino acids in the red-tide dinoflagellate Alexandrium excavatum - UVphotoprotective compounds. J. Plankton Res. 12: 909-922

Chioccara, F., Misuraca, G., Novellino, E., Porta, G. (1986a). Occurrence of two new mycosporine-like amino acids mytilins $\mathrm{A}$ and $\mathrm{B}$ in the edible mussel, Mytilus galloprovincialis. Tetrahedron Lett. 34: 3181-3182

Chioccara, F., Zeuli, L., Novellino, L. E. (1986b). Occurrence of mycosporine related compounds in sea urchin eggs. Comp. Biochem. Physiol. 85B: 459-461

Conand, C. (1991). Long-term movements of some tropical sea-cucumbers monitored by tagging and recapture. In: Yanagisawa, T., Yasumasu, I., Oguro, C., Suzuki, N., Motokawa, T. (eds.) Biology of Echinodermata. Pro- 
ceedings of the seventh international echinoderm conference, Atami, Japan. A. A. Balkema, Rotterdam, p. 169-175 Dunlap, W. C., Banaszak, A. T., Rosenzweig, T T., Shick, J. M. (1991). Ultraviolet light-absorbing compounds in coral reef holothurians: organ distribution and possible sources. In: Yanagisawa, T., Yasumasu, I., Oguro, C., Suzuki, N., Motokawa, T. (eds.) Biology of Echinodermata. Proceedings of the seventh international echinoderm conference, Atami, Japan. A. A. Balkema, Rotterdam, p. 560

Dunlap, W. C., Chalker, B. E. (1986). Identification and quantitation of near-UV absorbing compounds (S-320) in a hermatypic scleractinian. Coral Reefs 5: 155-159

Dunlap, W. C., Chalker, B. E., Oliver, J. K. (1986). Bathymetric adaptations of reef-building corals at Davies Reef, Great Barrier Reef, Australia. III. UV-B absorbing compounds. J. exp. mar. Biol. Ecol. 104: 239-248

Dunlap, W. C., Williams, D. McB., Chalker, B. E., Banaszak, A. $T$ (1989). Biochemical photoadaptation in vision: UVabsorbing pigments in fish eye tissues. Comp. Biochem. Physiol. 93B: 601-607

Favre-Bonvin, J., Bernillon, J., Salain, N., Arpin, N. (1987). Biochemistry of mycosporines: mycosporine glutaminol in Trichothecium roseum. Phytochemistry 26: 2509-2514

Féral, J.-P. (1980). Cuticule et bactéries associées des épidermes digestif et tégumentaire de Leptosynapta galliennei (Herapath) (Holothuroidea: Apoda) - premières données. In: Jangoux, M. (ed.) Echinoderms: present and past. A. A. Balkema, Rotterdam, p. 285-290

Féral, J.-P., Cherbonnier, G. (1986). Les holothurides. In: Guille, A., Laboute, P., Menou, J.-L. (eds.) Guide des étoiles de mer, oursins et autres échinodermes du lagon de Nouvelle-Calédonie. Éditions de l'ORSTOM, Institut Français de Recherche Scientifique pour le Développement en Coopération, Paris, p. 55-107

Féral, J.-P., Massin, C. (1982). Digestive systems: Holothuroidea. In: Jangoux, M., Lawrence, J. M. (eds.) Echinoderm nutrition. A. A. Balkema, Rotterdam, p. 191-212

Fleischmann, E. M. (1989). The measurement and penetration of ultraviolet radiation into tropical marine water. Limnol. Oceanogr 34: 1623-1629

Floss, H. G. (1979). The shikimate pathway. In: Swain, T. Harborne, J. B., Sumere, C. F. van (eds.) Recent advances in phytochemistry: biochemistry of plant phenolics. Plenum Press, New York, p. 59-89

Hammond, L. S. (1982). Patterns of feeding and activity in deposit-feeding holothurians and echinoids (Echinodermata) from a shallow back-reef lagoon, Discovery Bay, Jamaica. Bull. mar. Sci. 32: 549-571

Hirata, Y., Uemura, D., Ueda, K., Takano, S. (1979). Several compounds from Palythod tuberculosa (Coelenterata). Pure appl. Chem. 51: 1875-1883

Holland, N. D. Nealson, K. H. (1978). The fine structure of the echinoderm cuticle and the subcuticular bacteria of echinoderms. Acta Zool. 59:169-185
Jerlov, N. G. (1950). Ultraviolet radiation in the sea. Nature 116: $111-112$

Karentz, D., McEuen, F. S., Land, M. C., Dunlap, W. C. (1991). Survey of mycosporine-like amino acid compounds in Antarctic marine organisms: potential protection from ultraviolet exposure. Mar. Biol. 108: 157-166

Levin, V. S., Kalinin, V. I., Stonik, V. A. (1984). Chemical characters and taxonomic revision of holothurian Bohadschia graeffei (Semper) as refer to erection of a new genus. Biologia Morya 1984 (3): 33-38 (in Russian)

Moriarty, D. J. W. (1982). Feeding of Holothuria atra and Stichopus chloronotus on bacteria, organic carbon and organic nitrogen in sediments of the Great Barrier Reef. Aust. J. mar. freshwat. Res. 33: 255-263

Moriarty, D. I W., Pollard, P. C., Hunt, W. G., Moriarty, C. M.. Wassenberg, T. J (1985). Productivity of bacteria and microalgae and the effect of grazing by holothurians in sediments on a coral reef flat. Mar. Biol, 85: 293-300

Nakamura, H., Kobayashi, J., Hirata, Y (1981). Isolation and structure of a 330-nm UV-absorbing substance. Asterina330 from the starfish Asterina pectinifera. Chem. Lett. 28: $1413-1414$

Runnstrom, S. (1927). Uber die Entwicklung von Leptosynapta inhaerens. Bergens Mus. Ärbok, Naturvid. rek., Bergen

Shibata, K. (1969). Pigments and a UV-absorbing substance in corals and a blue-green alga living in the Great Barrier Reef. Plant cell Physiol. 10: 325-335

Shick, J. M., Lesser, M. P., Stochaj, W. R. (1991). Ultraviolet radiation and photooxidative stress in zooxanthellate Anthozoa: the sea anemone Phyllodiscus semoni and the octocoral Clavularia sp. Symbiosis 10: 145-173

Sivalingam., P. M., Ikawa, T., Yokohama, Y., Nisizawa, K. (1974). Distribution of a 334 UV-absorbing substance in algae, with special regard of its possible physiological roles. Bot. Mar. 17: 23-29

Smith, R. C., Baker, K. G. (1979). Penetration of UV-B and biologically effective dose-rates in natural waters. Photochem. Photobiol. 29: 311-323

Takano, S., Nakanishi, A. Uemura, D., Hirata, Y (1979). Isolation and structure of a $334 \mathrm{~nm}$ UV-absorbing substance, porphyra-334 from the red alga Porphyra tenera Kjellman. Chem. Lett., p. 419-420

Takano, S., Uemura, D., Hirata, Y (1978). Isolation and structure of a new amino acid, palythine, from the zoanthid Palythoa tuberculosa. Tetrahedron Lett. 26: $2299-2300$

Tsujino, I., Yabe, K., Sekekawa, I. (1980). Isolation and structure of a new amino acid, shinorine, from the red algae, Chondrus yendoi Yamada et Mikami. Bot. Mar. 23: 65-68

Wood. W. F. (1987). Effect of solar ultra-violet radiation on the kelp Eklonıa radiata. Mar. Biol. 96: 143-150

Yoshida, S. (1969). Biosynthesis and conversion of aromatic amino acids in plants. A. Rev. plant Physiol. 20: 41-62 